\title{
In the Name of ESP - Comments on the Recent Discussion on College English Teaching Reform in China
}

\begin{abstract}
XUE Mei
Shanghai Institute of Technology, Shanghai, China

One of the most controversial debate topics in current College English teaching is whether EGP (English for General Purposes) should be replaced by ESP (English for Specific Purposes). The latest College English Curriculum issued by MOE (Ministry of Education) does not reflect the trend of developing College English Teaching by focusing on ESP, but rather on improving general English course books. However, the first local College English Curriculum published in 2012 in Shanghai focuses on developing ESP and English for academic purpose as its teaching objectives. This paper analyzes different definitions of ESP in China's education setting, compares different views on handling the relationship between EGP and ESP in China's College English Reform, and explores how to apply an appropriate notion of EGP to College English teaching in China.
\end{abstract}

Keywords: College English language education, EGP, ESP, EAP

\section{Introduction}

College English (CE) is a required basic course for non-English majors in almost all universities and colleges in the People's Republic of China. CE teaching has undergone over 60 years of development with frequent reforms of curricula and the shifts of teaching reform to keep up with the latest Western TESOL (Teaching English to Speakers of Other Languages) pedagogies (Ruan \& Jacob, 2009). In 21st century, the research interest turned to the exploration of the genre of the teaching material. Recently, disputes arose on whether College English as a general foundation course, which is named English for General Purpose (EGP) should be replaced by English courses serving for students' majors, which is called English for Specific Purposes (ESP).

The latest College English Curriculum issued by MOE (Ministry of Education) does not reflect the trend of developing tertiary English by focusing on ESP, but rather on successfully completing general English course books (GAO, 2013). However, the first local College English Curriculum published in 2012 in Shanghai focuses on developing ESP and English for academic purpose as its teaching objectives. Professor CAI defines academic English as the transition from EGP to ESP. It has two levels: First level is general academic English and then professional academic English. New textbooks of College English for academic purposes have been published and applied in the colleges volunteered for trial experimentation.

The reason why EGP should be replaced by ESP, as Professor CAI claims, is that the English curriculum requirement for high school education has been closer and closer to that of the college English learning. There is often the case that students accepted by top universities have already met the requirement of College English

XUE Mei, associate professor, B.A., Department of Foreign Languages, Shanghai Institute of Technology. 
Curriculum. Therefore, college students would lose interest in continuing the learning of general English. Meanwhile, the course design embodied in current curriculum cannot meet the social expectations on college graduates to have good English proficiency in the field of a particular profession (CAI, 2012). Professor CAI claims that it is time for College English teaching to shift gradually to ESP. EGP would be a meaningless repetition of what students have already learnt in secondary education due to the fast advancement of high school English education.

Another view on the content of College English education is that English learning should be part of liberal arts education, helping students create critical views on Western culture and values. The familiarity with the cultural difference between east and west helps promote the intercultural communicative competence (WANG, 2011). Professor WANG Shou-ren, the representative of this view claims that English language should be taught not only as a vehicle for gaining access to Western science and technology, or for diplomatic and intellectual interaction with the West, but also to "to promote mutual understanding and tolerance, respect for identities and cultural diversity through more effective international communication" as cited from the document of Common European Framework of Reference for Languages.

\section{The Definitions of EGP and ESP and Their Acceptance in China's Education Setting}

In most cases, the definitions of the two terms were taken for granted in debates on whether EGP or ESP should be focused on College English teaching in China. The clarification of the definition should be the premise of the debate. The two terms defined by different scholars were accepted by different English teaching approaches.

According to Trimble, "'General English' is the mainstay of all fields, whatever the purpose for which the language is used" (Trimble, 1985, p. 6). General purpose English covers a vast domain and the boundaries of general English are indeed vague. Widdowson (1984) defines EGP in the similar way, pointing out that "...GPE (General Purpose English) is less specific and purposeful than ESP. What distinguishes them is the way in which purpose is defined, and the manner of its implementation" (p. 1). Trimble's view on EGP is the same as that of the English educators in China, saying that English for general purposes is, in fact, the foundation for later attainments in specialist field (Trimble, 1985, p. 6).

The approach of defining ESP as a specific domain of English learning is reflected in the previous debate about whether English teaching should focus on ESP or EGP in the 1980s in China. The origin of the dispute, as Professor ZHENG Shu-tang, a senior College English Textbook designer puts it, is the pursuit of efficiency in learning English for immediate use with the hypothesis that narrowing down the domain of English learning within one field, such as Science and Engineering, would be a shortcut.

Is the new trend of ESP a returning to the origin or a step forward? WEN qiu-fang, an expert on English language education and policy points out a brand new idea on EGP and ESP, holding that EGP should not be simply defined as basic English or English foundation. Prof. WEN views that the learning of ESP and EGP overlaps instead of separating from each other. This viewpoint is quite similar to that of McDonough (1984) who believes that it is inappropriate and counterproductive to separate EGP and ESP (p. 7). He claims that "Such fragmentation (the many branches of ESP such as EST, EOP, EAP...) is no more true than the opposite, monolithic view, which is often represented as ESP versus EGP..." (p. 8). Here it is felt that if the students possess some knowledge of English language, they will understand the kind of language that is related to their specialist field. So it is unnecessary to divide English into EGP and ESP. 
Professor WEN cites words of some scientists in Chinese Academy of Sciences, China's top institute of science, demonstrating that it is not enough for Chinese scientists to participate in international academic communication with only scientific English. International academic communication, as they put it, is not only the interchange of a specific scientific field but also a dialogue between and among different cultures, histories, and ideologies. Therefore, tertiary English language education should not restrict itself to only one domain of English learning.

\section{Another Connotation of ESP in College English Education Reform}

Hutchinson and Waters define ESP as an "approach" instead of a product, meaning that ESP is not a matter of teaching specialized varieties of English. It is not different in kind from any other form of language teaching. Helen Basturkmen (2006) said "whereas General English Language teaching tends to set out towards an often pretty indeterminate destination, setting sail through largely uncharted waters, ESP aims to speed learners through to a known destination" (p. 9). Nevertheless, within ESP, there are proposals and counterproposals, arguments, and counterarguments about the nature of the destination (views of what is meant by knowing a language for special purposes) and the best way of getting there (views of learning and teaching). Thus, although practical in orientation, ESP, like any other language teaching enterprise, is based on ideas about the nature of language, learning, and teaching.

Therefore, whether ESP is chosen to be the objective should not be the matter of direction of College English teaching in China. Rather, a notion of matching the pedagogy with the specific economic and social power as well as the initial English competence of the students and teachers is more important. The unified College English Curriculum Requirements cannot be attained in reality. First of all, the enrolment expansion in universities since 1999 ended up with a wider variety in students' initial English proficiency at different universities in different regions. Secondly, different regions at different development levels vary in the requirement of college graduates' English proficiency. Given these institutional and regional disparities, any nation-wide decision making should be based on the thorough investigation of all factors concerned. There should be multi-dimensional English courses to cater to students of different levels. The curriculum of college English education should leave room for teachers, curriculum developers, and provinces to determine how the goals should be reached and what additional topics should be addressed.

\section{Conclusion}

The debate on whether ESP or EGP should be the objective of College English teaching reflects different definitions of ESP in China's education setting. The problem of English education in tertiary level in China actually lies in a turning of concept that students' diversity apart from the nation's and the educational institute's basic requirements should be considered in the processes of curriculum development. This can be brought light by "needs analysis" in which the reasons behind the syllabus are determined in detail and in advance (cf. Nunan, 1991).

\section{References}

Basturkmen, H. (2006). Ideas and options in English for specific purposes. Mahwah, New Jersey, London: Lawrence Erlbaum Associates Publishers.

CAI, J. G. (2012). The justification and trend analysis of the extinction of College English in China. Foreign Language Research, $3-46$. 
GAO, L. L. (2013). College English curriculum requirements in China: Expectations and responses. Problems of Education in the 21st Century, 51.

Huthinson, T., \& Waters, A. (1987). English for specific purposes: A learning-centred approach. Cambridge: Cambridge University Press.

Mohammad, Z. (2015). Trends in ESP and EGP. Journal of Language Teaching and Research, 6(3), 679-684.

Nunan, D. (1991). Syllabus design. Oxford: OUP.

Ruan, Y., \& Jacob, W. J. (2009). The transformation of college English in China. Frontiers of Education in China, 4, $466-487$.

Trimble, L. (1985). English for science and technology: A discoursal approach. Cambridge: CUP.

WANG, S. R. (2011). Some thoughts on college English teaching in China. Foreign Language Learning Theory and Practice, 1 , $1-5$.

WEN, Q. F. (2014). Debate on ESP or EGP in college English teaching: Problem and solution. Foreign Languages and Foreign Languages Teaching, 1, 1-8.

Widdowson, H. G. (1984). Learning purpose and language use. Oxford: OUP.

XIAO, M., \& SHI, Y. (2008). Reflections on foreign language learning and teaching principles with Chinese characteristics. Foreign Languages in China, 5(3), 9-12.

ZHANG, Y. X. (2003). Speech at the forum on college English teaching reform. China University Teaching, 12, 9-11.

ZHANG, Y. X. (2008). Seize the opportunity, work better, and improve college English teaching comprehensively. Foreign Language World, 4, 2-7. 